KAVAKA 55: 58-64 (2020)

\title{
Onychomycosis caused by Fusarium concentricum Nirenberg \& O' Donnell and Fusarium proliferatum (Matsush.) Nirenberg in primary school children
}

\author{
Anjali Sharma and Geeta Sumbali* \\ Department of Botany, University of Jammu, BR Ambedkar Road Jammu-180006 (India) \\ *Corresponding authorEmail: geetasumbalippl@yahoo.co.in \\ (Submitted on August 29, 2020; Accepted on October 24, 2020)
}

\begin{abstract}
In the present study, two cases of onychomycosis (fungal nail infection) caused by Fusarium concentricum and Fusarium proliferatum in school children of Kalakot (Rajouri, $J \& K$ ) are described. The onychomycotic isolates were identified on the basis of cultural characters, diagnostic morphological features and by molecular characterization. Both these fusarial species are of uncommon occurrence and have not been recorded earlier as onychomycotic agents among children. The risk of nail contamination among children may be attributed to their careless behavior towards cleanliness and frequently playing with the soil, which is an important reservoir of Fusarium species.
\end{abstract}

Keywords: Onychomycosis, children, NCBI-Blast, Fusarium concentricum, F. proliferatum

\section{INTRODUCTION}

The genus Fusarium was described for the first time in 1809 by Link and since then it is known to be a very important plant pathogen (Williams and Mc Donald, 1983; Nelson et al., 1994). It is a cosmopolitan genus found in the tropical regions, temperate regions, deserts, mountainous and even the arctic zones (Hocquette et al., 2005). Fusarium species are widely distributed in the soil, air, water, subterranean and aerial plant parts, plant debris and other organic substrates (Nelson et al., 1994, Elvers et al., 1998). Its widespread distribution may be attributed to its ability to grow on a wide range of substrates and their efficient mechanism of dispersal (Burgess, 1981).

Fusarium species may occasionally cause infection in animals also (Evans et al., 2004), but in man, it is known to cause broad spectrum of infections, including superficial (keratitis and onychomycosis), locally invasive, disseminated infection, allergic diseases (sinusitis) and mycotoxicosis in animals and humans after having contaminated food (Wickern, 1993; Nucci and Annaissie, 2002). It is known to be an opportunistic pathogen and most of the identified pathogens belong to the Fusarium solani species complex (FSSC), Fusarium fujikuroi species complex (FFSC) and Fusarium oxysporum species complex (FOSC) (Kidd et al., 2016).

Onychomycosis is characterized by nail thickening, discolouration and separation of the nail unit. Earlier, onychomycosis was known to be caused by one of the three genera (Trichophyton, Epidermophyton and Microsporum) known as dermatophytes. However, now-a-days, nondermatophytes have been reported from various countries worldwide as the causal agents of a number of onychomycotic cases (Farwa et al., 2011; Bhou and Sumbali, 2015; Kotwal et al., 2018). Among the non-dermatophytes, Fusarium is emerging as one of the most important etiological agents of onychomycosis. Its frequent isolation from dystrophied nails is being suspected as a primary nail pathogen rather than a secondary invader following dermatophytic infection
(Jandial and Sumbali, 2012; Morales-Cardona et al., 2014; Bombace et al., 2016). Fusarium species are reported to cause $9-44 \%$ of the nail invasions caused by non-dermatophytic moulds (Kauffmann-Lacroix et al., 2005).The increasing incidence of Fusarium species as onychomycotic agents is attributed to the disseminated infections, especially in patients with underlying immunosuppressive conditions (Guarro and Gene, 1995) and other factors like close contact with soil, walking barefoot, wearing ill-fitting shoes or open sandals, use of commercial swimming pools, trauma, etc (Comparot et al., 1995). In this communication, we report cases of fusarial onychomycosis caused by Fusarium concentricum and $F$. proliferatum among two school children of Kalakot, Rajouri district (Union Territory of Jammu and Kashmir), India. Both these species are of uncommon occurrence and are being reported for the first time as onychomycotic agents among children.

\section{MATERIALS AND METHODS}

\section{Sampling and isolation}

The study was conducted between January 2018 and December 2019, wherein dystrophied nail samples were collected from school children of Kalakot, Rajouri district (J\&K), India. Sampling was done by first swabbing the deformed nails with $70 \%$ ethanol to remove any superficial microorganism. Then the nail clippings and scrapings were collected from the deformed nails, kept in pre-sterilised polythene bags and were brought to the laboratory. These nail samples were inoculated in petridishes plated with Sabouraud's Dextrose Agar (SDA) medium that was supplemented with chloramphenicol $(0.05 \mathrm{mg} / \mathrm{mL})$. The inoculated petridishes were incubated at $28^{\circ} \mathrm{C}$ for 10 days and were examined periodically. Isolation of the same fungus in culture on more than two consecutive occasions was taken as the criterion to consider the organism as a probable pathogen. All procedures performed in studies involving human participants were in accordance with the ethical standards of the Animal and Human Experimentation Ethics Committee (AHEEC), University of Jammu, Jammu (JU/SBT/17/1360 
Dated: 22/12/17), which follows the guidelines laid by Indian Council of Medical Research (ICMR), New Delhi, India.

\section{Mycological characterization of fungal pathogens}

The filamentous fungal pathogens were identified mycologically by studying their colony characteristics, preparing lactophenol cotton blue mounts and by following the published literature (Nirenberg and O'Donnell, 1998;Leslie and Summerell, 2006; Wang et al., 2013). The cultural features such as colour, odour and growth rate of the recovered pathogens were observed on potato dextrose agar (PDA) medium. For microscopic examination, the fungal pathogens were transferred to synthetic low nutrient agar (SNA) medium (KH2PO41 g; KNO3 $1 \mathrm{~g}$; MgSO4•7H2O 0.5 g; KCl 0.5 g; Glucose 0.2 g; Sucrose $0.2 \mathrm{~g}$ and Agar $20 \mathrm{~g}$ ), incubated for 10 days at $28^{\circ} \mathrm{C}$ and examined for morphological criteria like degree of conidiophore branching, monophialidic or polyphialidic condition, microconidia in balls or chains, shape of conidia and production of chlamydospores. Petriplate cultures were viewed under low power (100X) on an Olympus microscope to monitor features of the aerial mycelium and sporulation (whether in chains or balls). Once the points of sporulation were identified, they were removed with cellotape and mounted on a microscopic glass slide in a drop of lactophenol cotton blue and viewed at 400X and 1000X on an Olympus compound microscope where diagnostic morphological features were recorded and measurements were taken. Photographs of colonies were taken by using Canon camera (model IXUS 125 HS 16.1 mega pixels), whereas diagnostic morphological features were recorded photographically on a Nikon microscope (model Eclipse E400) fitted with Samsung SDC-312 digital camera.

\section{Molecular characterization of fungal pathogens}

Numerous studies have shown that morphology alone is not a sufficient method for species determination, but molecular characterization is also essential (Alcazar-Fuoli et al., 2008). Therefore, identification of the recovered Fusarium species was carried out at the sequencing facility of National Centre for Microbial Resource (NCMR), Pune (India). At the facility, genomic DNA was isolated by the standard phenol/chloroform extraction method of Sambrook et al. (1989). Extraction was followed by PCR amplification of the ITS regions using universal primers ITS 1 (5'-TCC GTA GGT GAA CCT GCG G-3') and ITS 4 (5'-TCC TCC GCT TAT TGA TAT GC-3'). The amplified ITS PCR product was purified by $\mathrm{PEG}-\mathrm{NaCl}$ precipitation and directly sequenced on an ABI ${ }^{\circledR}$ 3730XL automated DNA sequencer (Applied Biosystems, Inc., Foster city, CA) as per manufacturer's instructions. Essentially, sequencing was carried out using Lasergene package followed by NCBI-BLAST against sequences from type material for tentative identification (Boratyn et al., 2013). The confirmed sequences were submitted to Genbank of National Centre for Biotechnology Information, Maryland, USA to obtain GenBank accession number.

\section{RESULTS}

The dystrophied fingernail and toenail samples of two school children from Kalakot, Rajouri district of J\&K (India) when cultured on Sabouraud's dextrose agar (SDA) medium yielded two species of Fusarium. The onychomycotic details and etiological agents of onychodystrophies are described below:

Case 1: Onychomycosis was detected in an 11-year-old school boy whose big toenail was involved (Fig. 1A). The infection evolved 4 years back from the distal end with the thickening of the nail, which later on developed a longitudinal streak on the middle of the nail. After the growth of the nail to certain level, the nail splitted from middle. The colour of the nail was light yellow. The symptoms suggest a case of distal subungual onychomycosis (DSO).

In this case, Fusarium concentricum Nirenberg \& O' Donnell was recovered as the causal agent (Fig. 1). Colonies pink, cottony, slightly raised from the centre, fast growing, 25$27 \mathrm{~mm}$ in diameter in 7 days on PDA medium (Fig. 1B). No pigmentation was observed. Sporulation started after 4 days in the aerial mycelium. Conidiophores arise laterally on hyphae in the aerial mycelium and were unbranched.

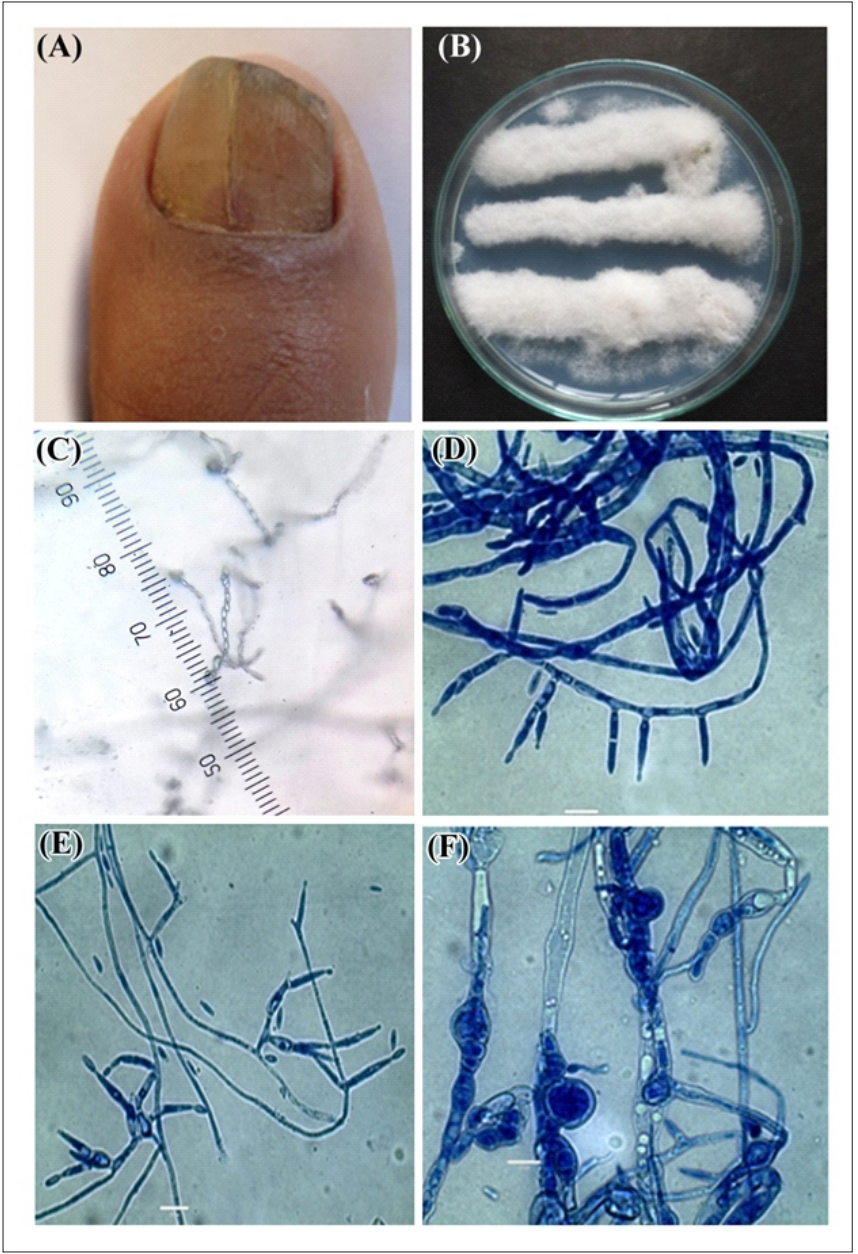

Fig. 1 A, Dystrophied toenail of case 1. B, Colonies of Fusarium concentricum on PDA medium. C, Microconidia in chains. D,E, Microphotographs showing microconidia formed from monophialides and polyphialides. F, Mycelial swellings (Bars= $10 \mu \mathrm{m})$ 


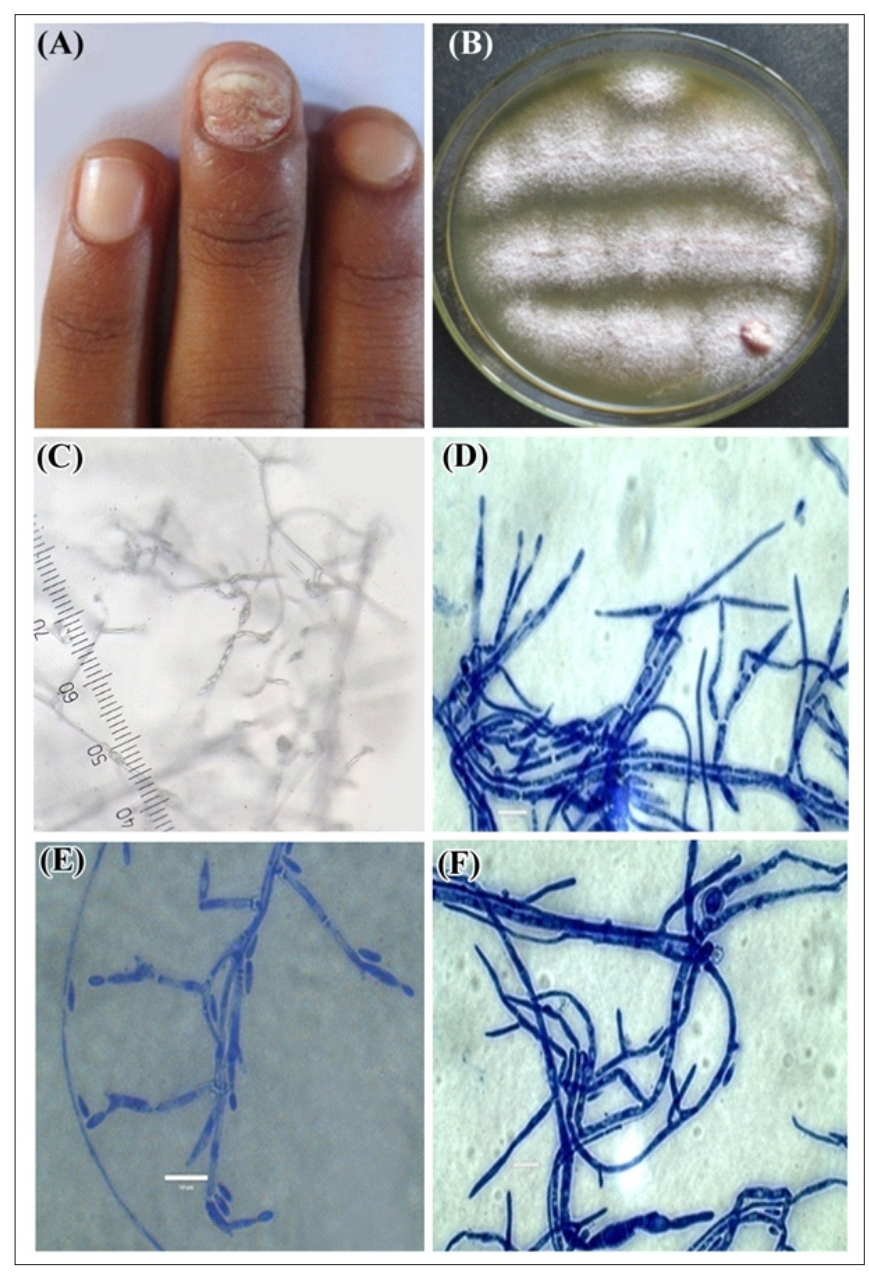

Fig. 2. A, Dystrophied fingernail of case 2. B, Colonies of Fusarium proliferatum on PDA medium. C, Microconidia in chains. D,E, Microphotographs showing microconidia formed from monophialides and polyphialides. F, Mycelial swellings (Bars= $10 \mu \mathrm{m})$.

Phialides monophialidic as well as polyphialidic, almost cylindrical, measuring 9.6-19.2×1.6-3.2 $\mu \mathrm{m}$. Microconidia adhering in chains, almost clavate with a flattened base, 0 septate, measuring 6.4-11.2×1.6-2.4 $\mu \mathrm{m}$. Macroconidia not produced. Mycelial swellings present (Fig. 1C-F).

Case 2: Onychomycosis was detected in a 9-year-old school girl whose left hand middle fingernail was involved (Fig. 2A). The infection had evolved three years back from the proximal end of the nail and was progressing towards the distal end, hence suggesting a case of proximal lateral subungual onychomycosis (PLSO). The texture of the nail was rough and colour was creamish white. The middle portion of the nail was extensively affected and at times small pieces of nail scrapings were also observed to shed off.

In this case, Fusarium proliferatum (Matsush.) Nirenberg was recovered as the causal agent (Fig. 2).Colonies on PDA showing average growth rate of $32 \mathrm{~mm}$ in 4 days at $28^{\circ} \mathrm{C}$. Aerial mycelium white with light purplish tinge, cottony to velvety; reverse reddish brown (Figure 2B). Conidiophores mainly prostrate, unbranched with one or whorl of phialides at the tip. Phialides flask-shaped, mono- and polyphialidic, up to $23 \mu \mathrm{m}$ long and $2.4 \mu \mathrm{m}$ wide. Microconidia borne in chains, ovoid in shape, 0 septate, measuring 5.2-9.6 $\times 1.6-2.4 \mu \mathrm{m}$. Macroconidia were not formed. Mycelial swellings present (Fig. 2 C-F).

\section{Molecular characterization of the recovered fungal pathogens}

Molecular identification of the fungal pathogens recovered from infected nails of the patients was done on the basis of rRNA gene sequence. The obtained ITS sequences were aligned using BLAST tool against the NCBI nucleotide database (http://blast.ncbi.nlm.nih.gov/) for most homologous sequences. The percentage similarity of the identified pathogens using NCBI- BLASTn was $99 \%$. The pathogens were identified as Fusarium concentricum (Accession No. MT337557.1) and Fusarium proliferatum (Accession No. MT337571.1). The strain numbers given to these Fusarium species are ACR-1 and ACR-3, respectively.

The evolutionary history was inferred by using the Maximum Likelihood method based on the Tamura-Nei model (Tamura and Nei, 1993). The bootstrap consensus tree inferred from 1000 replicates is taken to represent the evolutionary history of the taxa analyzed. In case of ACR-1, the analysis involved 43 nucleotide sequences and evolutionary analyses were conducted in MEGA6 (Tamura et al., 2013) as shown in fig. 3. In case of ACR-3, the analysis involved 40 nucleotide sequences and evolutionary analyses were conducted in MEGA6 as presented in fig. 4.

\section{DISCUSSION}

Fusarial onychomycosis has been reported around the globe with prevalence usually ranging from 0.97-12.9 per cent (Guilhermetti et al., 2007; Omar et al., 2013; Ranawaka et al., 2015; Martínez-Herrera et al., 2015; Diongue et al., 2017). Studies have even suggested that Fusarium species are the main causative agents of onychomycosis among the non-dermatophytes (Cardona, 1990; Castro et al., 2008) and may also cause other diseases in human beings like invasive fusariosis (Lobaton-Ramirez et al., 2017), keratitis (Cuero, 1980) and pulmonary nodule formation (Moreno et al., 2008).

A number of Fusarium species have been reported as onychomycotic agents and these include $F$. solani, $F$. oxysporum, $F$. dimerum, $F$. subglutinans, $F$. equiseti, $F$. heterosporum, $F$. pallidoroseum, $F$. chlamydosporum, $F$. verticilloides, $F$. keratoplasticum, $F$. petroliphilum, $F$. falciforme and F. proliferatum (Godoy-Martinez et al., 2009; Jandial and Sumbali, 2012; Ranawaka et al., 2015; Bhou and Sumbali, 2015; Ray et al., 2016; Rosa et al., 2017). Most of them have been recovered from the dystrophied nails of adults with predominance in the females (Ranawaka et al., 2012; Diongue et al., 2017). According to Chabasse and Pihet (2014), fusarial onychomycosis is usually a disease of the elderly people as it increases with age.

During the present study, two primary school children of 9and 11-years of age were found to have dystrophied middle 


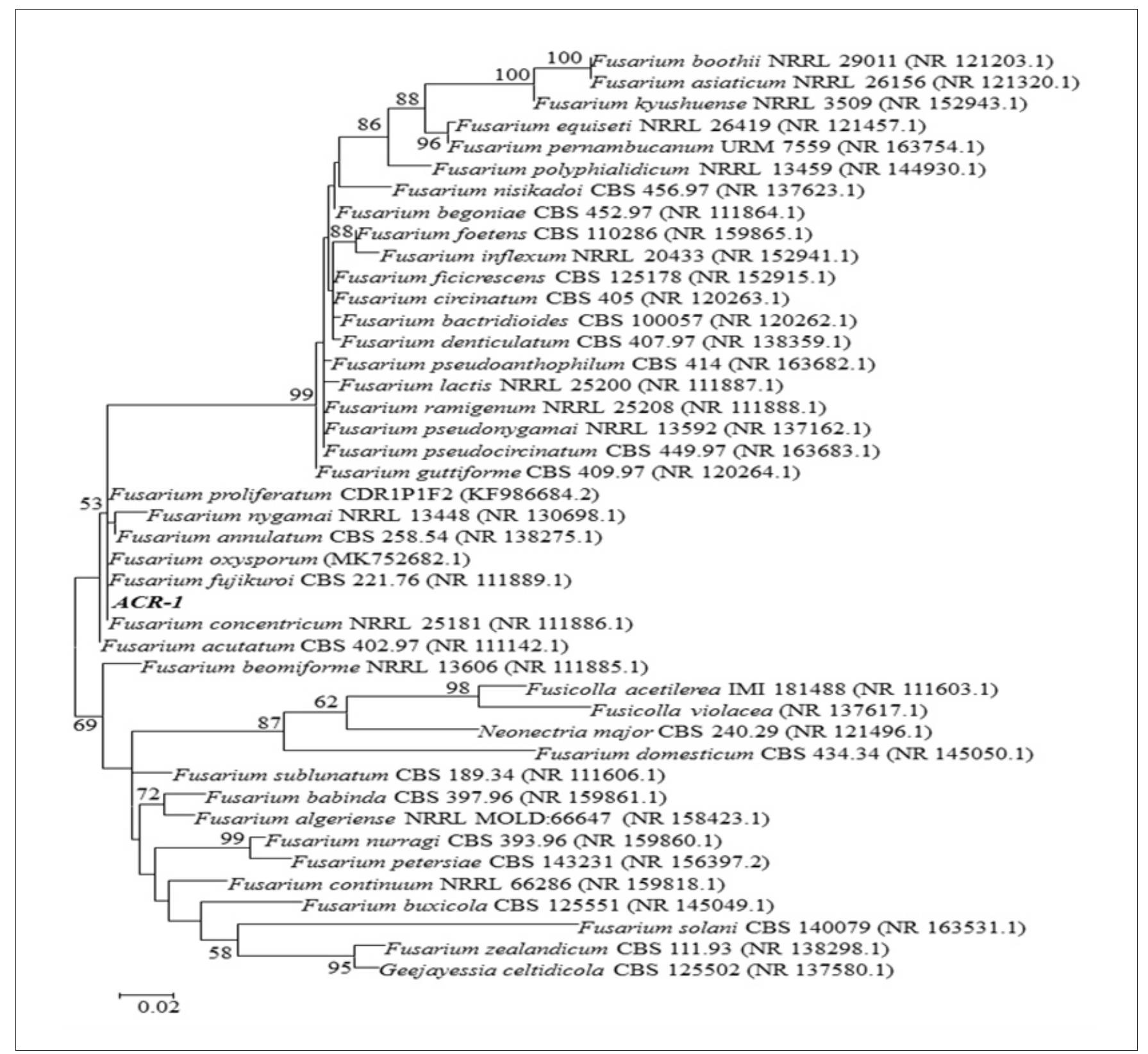

Fig. 3. Molecular phylogenetic relationship among Fusarium species with the reference taxa.

fingernail and big toenail, which were infected with $F$. proliferatum and $F$. concentricum, respectively. Of these, $F$. concentricum has not been reported so far as onychomycotic whereas $F$. proliferatum has been reported to cause onychomycosis in elderly people (Hattori et al., 2005; Brasch and Shimanovich, 2012; Bhou and Sumbali, 2015). Both these species belong to Fusarium fujikuroi species complex (FFSC), which is one of the larger groups within the genus Fusarium (Nirenberg and O'Donnell, 1998; O'Donnell et al., 2000; Al-Hatmi et al., 2015). So far, only Fusarium oxysporum, F. solani, F. pallidoroseum, F. chlamydosporum and $F$. verticilloides have been reported to cause onychomycosis among children (Romano et al., 2005; Carvalho et al., 2014; Bhou and Sumbali, 2015; Kotwal,
2018). Contamination of nails in case of children usually occurs because they walk barefooted or wear open sandals or frequently play with soil and sand. Since Fusarium species are well distributed soil inhabitants with their ability to be saprophytes or parasites, therefore it is an important risk factor for causing fusarial onychomycosis in children.

\section{CONCLUSION}

Onychomycosis is traditionally known to be a disease of the elderly, with an increase in the prevalence above the age of 60 years. However, the present diagnosis of onychomycosis among the two primary school children cannot be excluded in view of the nail abnormalities, mycological studies and molecular studies, which are always mandatory. 


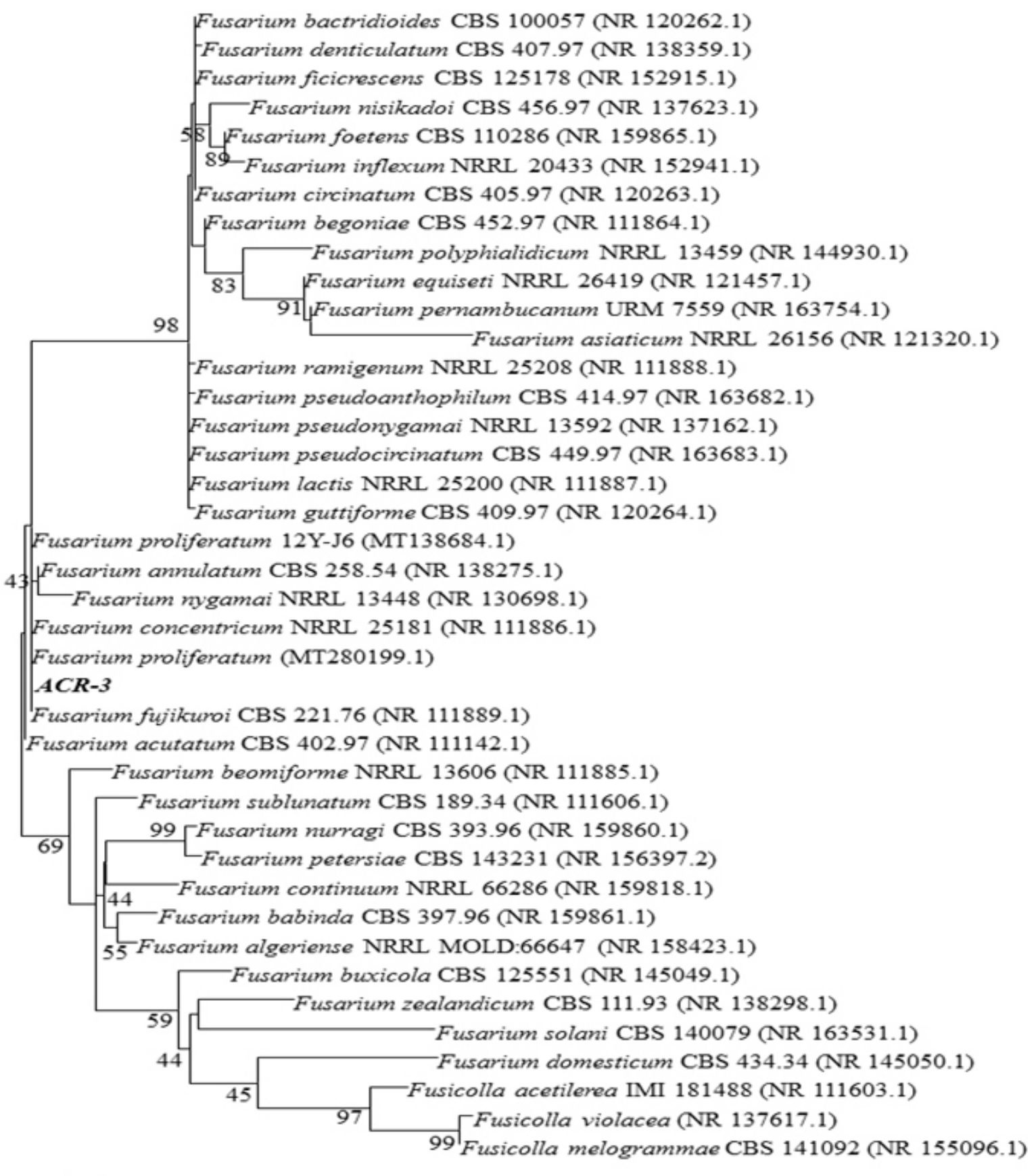

$\overrightarrow{0.02}$

Fig. 4. Molecular phylogenetic relationship among Fusarium species with the reference taxa.

During the present investigation, two Fusarium species were recovered as the main pathogens causing nail dystrophies in two school children. The isolation of these two Fusarium species, that is, F. concentricum and $F$. proliferatum from the infected nails suggests that these species can play an important role in human nail dystrophies other than causing plant diseases. As the children are more careless about cleanliness of hands and feet, they may acquire fungal infections during sports activity or through the contaminated environment. Among the non-dermatophytic nail infections, Fusarium species play a very important role as they are known to cause variety of infections like keratitis, onychomycosis, eumycetoma, skin lesions and other disseminated infections in immunocompromised patients. Therefore, correct identification of the fungal pathogens causing nail dystrophies is of utmost importance so that 
appropriate prophylactic treatment can be recommended. In our case, no immunodeficiency was noted in both the children.

To the best of our knowledge, there is no documented report of $F$. concentricum and $F$. proliferatum as the causative agents of onychomycosis in children. Therefore, they are new additions to the list of fungi causing onychomycosis among children.

\section{ACKNOWLEDGEMENTS}

The authors are thankful to the Head, Department of Botany, University of Jammu (India) for providing laboratory facilities and to the Special Assistance Programme (DRS-II) of University Grants Commission, New Delhi (India) for providing financial assistance during the period of research.

\section{REFERENCES}

Alcazar-Fuoli, L., Mellado, E., Alastruey-Izquierdo, A., Cuenca-Estrella, M. and Rodriguez-Tudela, J.L. 2008. Aspergillus section fumigati: Antifungal susceptibility patterns and sequence-based identification. Antimicrob. Agents Chemother. 52:1244-1251

Al-Hatmi, A.M., Normand, A.C., van Diepeningen, A.D., Hendrickx, M., de Hoog, G.S. and Piarroux, R. 2015. Rapid species-level identification of opportunists in the Fusarium fujikuroi species complex using MALDI-TOF mass spectrometry. Future Microbiol. 10:1939-1952.

Bhou, R. and Sumbali, G. 2015. Fusarial onychomycosis-an unrecorded report from Jammu district (India). Am. Int. J. Res. in Formal, Applied \& Natural Sciences. 12: $21-26$

Bombace, F., Iovene, M.R., Galdiero, M., et al. 2016. Nondermatophytic onychomycosis diagnostic criteria: an unresolved question. Mycoses 59:558-565.

Boratyn, G., Camacho, C., Cooper, P., Coulouris, G., et al. 2013. BLAST: A more efficient report with usability improvements. Nucleic Acids Res. 41. 10.1093/nar/gkt282.

Brasch, J. and Shimanovich, I. 2012. Persistent fingernail onychomycosis caused by Fusarium proliferatum in a healthy woman. Mycoses 55:86-9. doi:10.1111/j.1439-0507.2011.02041.x

Burgess, L.W. 1981. General ecology of the Fusaria. In: Fusarium: Diseases, biology, and taxonomy. (Eds.: Nelson, P.E., Toussoun, T.A. and Cook, R.J.) University Park, Pennsylvania, USA: The Pennsylvania State University Press; pp. 225-235.

Cardona, N.M. 1990. Hialohifomicosis por Fusarium Espectroclínico. Revista CES Medicina. 4: 53-56.

Carvalho, V., Vicente, V., Werner, B., Gomes, R., et al. 2014. Onychomycosis by Fusarium oxysporum probably acquired in utero. Med. Mycol. Case Rep. 6:58-61.

Castro López, N., Casas, C., Sopo, L., et al. 2008. Fusarium species detected in onychomycosis in Colombia. Mycoses 52: 350-356.

Chabasse, D. and Pihet M. 2014. Onychomycosis due to molds. J. Mycol. Med. 24:261-268.

Comparot, S., Reboux, G., van Landuyt, H., Guetarni, L. and Barale Th. 1995. Fusarium solani: Un casrebelled'intertrigo. J. Micol. Méd. 5: 119-121.

Cuero, R. 1980. Ecological distribution of Fusarium solani and its opportunistic action related to mycotic keratitis in Cali, Colombia. J. Clin. Microbiol. 12: 455-461.

Diongue, K., Ndiaye, M., Seck, M., Diallo, M., Badiane, A. and Ndiaye, D. 2017. Onychomycosis caused by Fusarium spp. in Dakar, Senegal: Epidemiological, clinical, and mycological study. Dermatol. Res. Pract. 1-4. doi:10.1155/2017/1268130.

Elvers, K.T., Leeming, K., Moore, C.P. and Lappin-Scott, H.M. 1998. Bacterial-fungal biofilms in flowing water photo-processing tanks. J. Appl. Microbiol. 84: 607-618.

Evans, J., Levesque, D., De Lahunta, A. and Jensen, H.E. 2004. Intracranial fusariosis: A novel cause of fungal meningoencephalitis in a dog. Vet. Pathol. 41:510514

Farwa, U., Abbasi, S.A., Mirza, I.A., Amjad, A., Ikram, A., Malik, N. and Hanif, F. 2011. Non- dermatophyte moulds as pathogens of onychomycosis. J. Coll. Physicians surg. Pak. 21:597-600.

Godoy-Martinez, P., Nunes F., Tomimori, J., Urrutia M., Zaror, L., Silva, V. and Fischman, O. 2009. Onychomycosis in Sao Paulo, Brazil. Mycopathologia 168:111-116. doi:10.1007/s11046009-9209-5.

Guarro, J. and Gene, J. 1995. Opportunistic fusarial infections in humans. Eur. J. Clin. Microbiol. Infect. Dis. 14:741-754.

Guilhermetti, E., Takahachi, G., Shinobu, C.S., et al. 2007. Fusarium spp. as agents of onychomycosis in immuno-competent hosts. Int. J. Dermatol. 46: 822-826.

Hattori, N., Shirai, A., Sugiura, Y., et al. 2005. Onychomycosis caused by Fusarium proliferatum. Br. J. Dermatol. 153:647-9. Doi:10.1111/j.13652133.2005.06692.x

Hocquette, A., Grondin, M., Bertout, S. and Mallié, M. 2005. Acremonium, Beauveria, Chrysosporium, Fusarium, Onychocola, Paecilomyces, Penicillium, Scedosporium and Scopulariopsis fungi responsible for hyalohyphomycosis. J. Mycol. Med. 15:136149.

Jandial, S. and Sumbali G. 2012. Fusarial onychomycosis among gardeners: A report of two cases. Indian J. Dermatol. Venereol. Leprol. 78:229. 
Kauffmann-Lacroix, C., Villers, A., Gantier, J.C., Guillet, G., Wierzbicka, E. and Rodier, M.H. 2005. Onyxis and cutaneous ulcers due to Fusarium solani in a patient with diabetes mellitus. J. Mycol. Med. 15:150-154. doi: 10.1016/j. mycmed.2005.05.001.

Kidd, S., Halliday, C., Alexiou, H. and Ellis, D. 2016. Descriptions of medical fungi. (revised), Underdale: The National Library of Australia, $3^{\text {rd }}$ edition.

Kotwal, S. 2018. Studies on the prevalence, keratinase potential and management of fungi causing onychomycosis in Doda district (J\&K). Ph.D thesis, University of Jammu, Jammu.

Kotwal, S., Sumbali, G., Sharma, S. and Kaul, S. 2018. Detection of some new Trichosporon species from the dystrophied nails of three female members of a family from North Indian State of Jammu and Kashmir. Mycoses 61. DOI: 10.1111/myc. 12761.

Leslie, J.F. and Summerell, B.A. 2006. The Fusarium laboratory manual. Oxford, UK: Blackwell Publishing Ltd. Link 1809

Lobatón-Ramírez, J., Coronado-Negrete, A., RamírezBarranco, R., et al. 2017. Fusariosisdiseminada por Fusarium verticillioidesen un paciente con leucemiamieloideaguda. Rev Cienc Biomed. 7: 316322 .

Martínez-Herrera, E.O., Arroyo-Camarena, S., TejadaGarcía, D.L., Porras-López, C.F. and Arenas, R. 2015. Onychomycosis due to opportunistic molds. An Bras Dermatol. 90: 334-337.

Morales-Cardona, C.A., Valbuena-Mesa, M.C., Alvarado Z., et al. 2014. Non-dermatophyte mould onychomycosis: a clinical and epidemiological study at a dermatology referral centre in Bogota, Colombia. Mycoses 57: 284-293.

Moreno, N., Saavedra-Rodríguez, A., Sánchez-Morales, E. and García-Herreros, P. 2008. Fusariosisco monódulopulmonarsolitario. Rev. Fac. Med. 56: 257-261.

Nelson, P.E., Dignani, M.C. and Anaissie, E.J. 1994. Taxonomy, biology, and clinical aspects of Fusarium species. Clin. Microbiol. Rev. 7: 479-504.

Nirenberg, H.I. and O’Donnell, K. 1998. New Fusarium species and combination within the Gibberella fujikuroi species complex. Mycologia 90 : 434-458.

Nucci, M. and Anaissie, E. 2002. Cutaneous infection by Fusarium species in healthy and immunocompromised hosts: implications for diagnosis and management. Clin. Infect. Dis. 35: 909-920.

O’Donnell, K., Nirenberg, H.I., Aoki T. et al., 2000. A multigene phylogeny of the Gibberella fujikuroi species complex: Detection of additional phylogenetically distinct species. Mycoscience41: 61-78. https://doi.org/10.1007/BF02464387

Omar, B.J., Agnihotri, P., Pande, R.C., Upadhyay, G.C., Sakhuja, S. and Arosa, S.K. 2013. Nondermatophytic fungal infections among the dermatophytoses-a hospital based study. Indian $J$. Comm. Health 25: 34-38.

Ranawaka, R.R., Nagahawatte, A. and Gunasekara, T. 2015. Fusarium onychomycosis: Prevalence, clinical presentations, response to itraconazole and terbinafine pulse therapy, and 1-year follow-up in nine cases. Int. J. Dermatol. 54:1275-1282.

Ranawaka, R.R., de Silva, N. and Ragunathan, R.W. 2012. Non-dermatophyte mold onychomycosis in Sri Lanka. Dermatol Online J. 18:7.

Ray, R., Ghosh, M., Chatterjee, M., Chatterjee, N. and Banerjee, M. 2016. Case Report: Onychomycosis caused by Fusarium dimerum. J. Clin. Sci. Res. 5: 44-48.

Romano, C., Papini, M., Ghilardi, A. and Gianni, C. 2005. Onychomycosis in children: a survey of 46 cases. Mycoses 48: 430-437.

Rosa, P., Heidrich, D., Corrêa, C., Scroferneker, M., Vettorato, G., Fuentefria, A. and Goldani, L. 2017. Genetic diversity and antifungal susceptibility of Fusarium isolates in onychomycosis. Mycoses 60. doi:10.1111/myc.12638.

Sambrook, J, Fritschi, E.F. and Maniatis, T. 1989. Molecular cloning: a laboratory manual, Cold Spring Harbor Laboratory Press, New York.

Tamura, K. and Nei, M. 1993. Estimation of the number of nucleotide substitutions in the control region of mitochondrial DNA in humans and chimpanzees. Mol. Biol. Evol. 10: 512-526.

Tamura, K., Stecher, G., Peterson, D., Filipski, A. and Kumar, S. 2013. MEGA6: Molecular Evolutionary Genetics Analysis version 6.0. Mol. Biol. Evol. 30: 2725-2729. https://doi.org/10.1093/molbev /mst197

Wang, J.H., Feng, Z.H., Han, Z., Song, S.Q., Lin, S.H. and Wu, A.B. 2013. First report of pepper fruit rot caused by Fusarium concentricum in China. The American Phytopathological Society 97:1657 http://dx.doi.org/10.1094/PDIS-03-13-0325-PDN

Wickern, G.M. 1993. Fusarium allergic fungal sinusitis. J. Allergy Clin. Immunol. 92: 624-625.

Williams, R.J. and McDonald, D. 1983. Grain moulds in the tropics, problems and importance. Ann. Rev. Phytopathol. 21:153-178. 